\title{
INTERFERENCJE JEZZYKOWE I KULTUROWE W PRZEMYSKIEJ URBANONIMII
}

Słowa tematyczne: urbanonimy, pogranicze językowo-kulturowe, interferencje, Przemyśl

\section{WPROWADZENIE}

Przemyśl jest miastem ulokowanym na pograniczu polsko-ukraińskim. Od zarania dziejów był to teren sporny pomiędzy Koroną Polską i Rusiąa . W dziejach kontaktów polsko-ukraińskich można wyróżnić pięć okresów: 1) do połowy XIV wieku (ekspansja Rusi), 2) do końca XVIII wieku (ekspansja polska, polonizacja elit ukraińskich), 3) 1772-1918 — okres zaborów, 4) okres międzywojenny (wejście zachodniej Ukrainy w skład Polski), 5) okres powojenny (podzielenie obszaru granicą państwową, procesy nacjonalizacyjne po obu stronach granicy) (por. Wolnicz-Pawłowska, 1998, s. 456)².

Cechą charakterystyczną pogranicza polsko-ukraińskiego było to, że różnorodność etnosów pokrywała się w zasadzie z różnorodnością wyznań. Trzy największe skupiska to katoliccy Polacy, grekokatoliccy Ukraińcy oraz starozakonni Żydzi. Uzupełniały je mniejszości niemiecka i ormiańska ${ }^{3}$. Ta mieszanka żyła we względnej zgodzie do I wojny światowej; znacząco naruszyły ją dopiero krwawe walki Polaków z Ukraińcami w latach 1918-1920, którym towarzyszyło oskarżanie Żydów o sprzyjanie jednej ze stron. Ostateczny kres tej symbiozie przyniosła II wojna światowa i jej skutki polityczne.

${ }^{1}$ Wcześniej zapewne teren leżał na styku plemion zachodnio- i wschodniosłowiańskich; wielu badaczy wskazuje, że granicę między tymi dwoma zespołami stanowiło dorzecze Bugu (szerzej na temat rozpadu wspólnoty prasłowiańskiej zob. np. Walczak (1999).

${ }^{2}$ Inaczej periodyzują historię tych stosunków socjologowie, którzy pierwszy okres rozciągają do połowy XIX wieku, do czasu rozwoju świadomości narodowej na pograniczach (w tym okresie można mówić raczej o pograniczu w wymiarze społecznym czy klasowym, a nie terytorialnym, gdyż były to ziemie należące do Rzeczypospolitej); drugi okres trwa do II wojny światowej, a trzecim jest czas oddziaływania totalitaryzmu komunistycznego (Wojakowski, 2002, s. 98; Babiński, 1997, s. 65-70).

${ }^{3}$ Na ten temat zob. więcej: Wojakowski (2002, s. 99-101) i Budzyński (1993). 
Językoznawcy definiują pogranicze (w szczególności pogranicze językowe) jako „obszar geograficzno-kulturowy wzdłuż granicy językowej, na którym większość mieszkańców (lub określona grupa ludzi) wchodzi stale w kontakt językowy z językiem sąsiednim" (Wolnicz-Pawłowska, 1998a, s. 397). Socjologowie wyodrębniają z kolei pogranicza ze względu na dwa kryteria: przestrzenne - obszar wokół granic, i społeczne - obszar, „na którym występowały trwałe i wieloaspektowe kontakty między co najmniej dwoma zbiorowościami społecznymi" (Babiński, 2002, s. 14). Analizują oni pogranicza w kontekście ich oddalenia od centrum i związanymi z tym oddziaływaniami politycznymi, prawnymi, ekonomicznymi i kulturowymi (w tym religijnymi) różnych centrów. O ile granice dzielą, o tyle pogranicza łączą elementy różnych kultur, są naturalnym (w przeciwieństwie do często sztucznych granic) filtrem, swoistym pasem przejściowym, „obszarem półcienia” (Babiński, 1997, s. 42, 49). Nie wszystkie pogranicza mają jednakowy charakter, dlatego dokonuje się różnej ich typologii. Socjologowie często wyróżniają pogranicza stykowe i przejściowe, stare i nowe ${ }^{4}$, geograficzne i kulturowe, społeczne i administracyjne, izolowane i zintegrowane. Podkreśla się też dynamikę strategii interpretacyjnych pogranicza (Niedźwiedzka-Iwańczak, 2020, s. 286-290).

Pogranicze niemal zawsze związane jest $\mathrm{z}$ transferem i wzajemnym przenikaniem się wzorców językowych i kulturowych sąsiadujących ze sobą żywiołów. Interesujący nas obszar to pogranicze stare, przejściowe. Warto jednak podkreślić, że w miastach tego regionu — prócz Polaków i Ukraińców — zamieszkiwali także Żydzi i inne mniejszości. Sprawia to, że — podobnie, jak to stwierdzili H. Krasowska i O. Suchomłynow (2007, s. 56) na Bukowinie — trudno tu mówić o pograniczu kultur, a właściwszym terminem byłby tygiel kulturowy, swoista amalgamacja kulturowa.

O toponimii tego terenu w granicach historycznych województw bełskiego i ruskiego (z ziemią sanocką, przemyską, lwowską i halicką) wiele pisano w literaturze polskiej w odniesieniu do nazewnictwa miast i wsi, hydronimów oraz mikrotoponimiów. Analizowano etymologię, interferencje językowe, motywację i budowę tych nazw, zob. badania J. Riegera (1969), W. Makarskiego (1986; 1999), B. Czopek-Kopciuch (1988), E. Wolnicz-Pawłowskiej (np. 1998), A. Czapli (2011; 2018), M. Kopra (2019) i in. Zdecydowanie mniej uwagi poświęcano nazewnictwu miejskiemu na Kresach wschodnich ${ }^{5}$, dlatego warto się temu zagadnieniu uważniej przyjrzeć.

\footnotetext{
${ }^{4}$ W wypadku Przemyśla nie ma mowy o współcześnie rozwijanej teorii nowego pogranicza o nieokreślonym terytorium, definiowanego w kategoriach symbolicznych, jak to zrobił F. Barth (por. Babiński, 2002, s. 17-18; Niedźwiedzka-Iwańczak, 2020, s. 283).

${ }^{5}$ Por. publikacje A. Myszki i P. Wisza (2012), A. Myszki (2015) czy M. Kopra (2017).
} 
Do analizy wybrano nazwy miejskie jednego z najstarszych grodów pogranicza - Przemyśla. Początek historycznych wzmianek o mieście to X wiek ${ }^{6}$, lecz pierwsze określenia ulic odnotowano tu dopiero w piętnastowiecznych dokumentach (por. Sagan-Bielawa, 2004, s. 224). O nazewnictwie tego miasta pisała wprawdzie M. Sagan-Bielawa (2004; 2006), ale raczej w kontekście historii niż interferencji językowo-kulturowych. Warto zatem prześledzić, w jakim zakresie wielokulturowość miasta znalazła odzwierciedlenie w jego onimii.

\section{POŁOŻENIE — GRANICE POLITYCZNE}

Przemyśl to prastary gród leżący na stokach gór nad Sanem, nieopodal ujścia rzeki Wiar. Główną cechą jego położenia jest ulokowanie na historycznej granicy między Wschodem a Zachodem ${ }^{7}$. Za czasów I Rzeczypospolitej i Rzeczypospolitej Obojga Narodów gród był stolicą ziemi przemyskiej wchodzącej w skład województwa ruskiego, po rozbiorach stał się częścią Królestwa Galicji i Lodomerii (był trzecim co do wielkości miastem Galicji), w okresie międzywojennym wchodził w skład polskiego woj. lwowskiego. Po zmianach granic po II wojnie światowej znalazł się w obrębie województwa rzeszowskiego, potem przejściowo stał się miastem wojewódzkim (1975-1998), obecnie administracyjnie należy do województwa podkarpackiego. Położony $14 \mathrm{~km}$ od granicy z Ukrainą, jest znaczącym węzłem komunikacyjnym (przejście graniczne drogowe i kolejowe).

Onimicznie granicę i przynależność etniczno-administracyjną miasta wyznaczają dwa średniowieczne zamki: Zamek Ksiązat Ruskich ${ }^{8}$ — istniejący już tylko w tradycji ustnej; nawet jego położenie nie jest pewne; doszczętnie zniszczony prawdopodobnie podczas najazdu Wołochów w 1498 roku, oraz Zamek Kazimierzowski - wzniesiony w XIV wieku przez Kazimierza Wielkiego po przejęciu tych terenów od Rusi (Różański, 2001, s. 22-23). Obie nazwy to zróżnicowane formalnie struktury posesywne (pierwsza — z przydawką dopełniaczową, druga — z przymiotną; oba onimy są późniejsze niż obiekty).

Znaczący przyrost nazw miejskich w Przemyślu przypada na okres galicyjski (XVIII i XIX wiek). Miasto było wówczas rozdarte między Wschodem (Lwowem — stolicą Wschodniej Galicji) a Zachodem (Krakowem — miastem stołecznym Galicji Zachodniej), choć wyraźnie ciążyło ku pierwszemu z tych

\footnotetext{
${ }^{6}$ Pierwsze wzmianki źródłowe dotyczące Przemyśla odnajdujemy w latopisie Nestora „Powieść minionych lat”. Autor pod rokiem 6489 (981) pisze: „Poszedł Włodzimierz ku Lachom i zajął grody ich: Przemyśl, Czerwień i inne grody, które są i do dziś dnia pod Rusią” (Sielecki, 1999, s. 65).

${ }^{7}$ Zaliczany do historycznych Grodów Czerwieńskich, we wczesnym średniowieczu był terenem spornym Polski, Rusi i Węgier (Wolski, 1957, s. 8-9; dużo na ten temat zob. Malczewski, 2017).

${ }^{8}$ Wszystkie człony nazw zestawionych (również te uważane za gatunkowe, np. zamek, rondo, cmentarz, kościót, kamienica) zapisywane są wielką literą, z wyjątkiem spójników, przyimków i skrótów.
} 
miast. Widoczne jest to już w najstarszych urbanonimach: w XVI wieku wjazdu do miasta strzegły bramy, z których najokazalszą była Brama Lwowska, zwana też Brama Senatorska; kolejna brama, usadowiona przy moście na Sanie, zwana była Brama Wodna lub Brama Krakowska (Różański, 2001, s. 31), później też Sanowa lub Mostowa (Wolski, 1957, s. 76-77). Z czasem powstała jeszcze Brama Sanocka. Mimo że miasto miało więcej bram, to właśnie te trzy wyznaczały kierunek kontaktów Przemyśla, podkreślony nazwami ulic biegnących od bram.

$\mathrm{Na}$ wschód wiodła $u l$. Lwowska9 , na zachód - ul. Krakowska, nieco na południe - ul. Sanocka. Przypomnieć trzeba, że w toponimii miast ulice kierunkowe były tymi nazwami, które od zawsze określały strategiczne i geograficzne położenie: wskazywały najważniejsze kierunki handlowe, gospodarcze, administracyjne. Niemal do końca XIX wieku miały one charakter wyłącznie realistyczny ${ }^{10}$. Nazwy dwóch największych galicyjskich miast zostały utrwalone także w nazwach przemyskich przedmieść, a później osiedli: Przedmieście Lwowskie (pojawiające się już w dokumentach z lat 1521, 1629 i 1668) (Kramarz, 1930, s. 11, 29-30), obecnie os. Lwowskie, i Przedmieście Krakowskie, teraz os. Krakowskie. W latach międzywojennych w mieście była Cukiernia Lwowska Rosiewicza (Orłowicz, 1917, s. 10).

Dla przemyślan Lwów był miastem bardziej swoim niż Kraków — ze względu na odległość, podległość administracyjną, dostęp do edukacji. Po wojnie to się zmieniło, Lwów znalazł się po drugiej stronie granicy, mimo to wciąż pozostaje jeśli nie swój, to przynajmniej swojski i bliski. Nazwy utworzone w relacji do nazwy stolicy Galicji Wschodniej nie są usuwane z onimicznej przestrzeni Przemyśla, przeciwnie - są przechowywane w pamięci pokoleń, niezależnie od napięć społecznych i warunków politycznych. Zwłaszcza że do dziś żyją Polacy wykształceni na lwowskiej uczelni, urodzeni po drugiej stronie granicy. Widać to m.in. w życiorysach patronów przemyskich ulic, w których przeplatają się wątki polskie i ukraińskie; przemyskie, lwowskie, a nawet moskiewskie, np.: ul. Nestora ${ }^{11}$, ul. Bohdana Zaleskiego ${ }^{12}$, al. Harcmistrza Edwarda Heila ${ }^{13}$, ul. Emilii Gierczak ${ }^{14}$, ul. pptk. Kazimierza Gurbiela ${ }^{15}$.

${ }^{9}$ Istniejąca współcześnie ul. Lwowska jest nowa; pierwotna ul. Lwowska, ta z motywacją realistyczną, to obecna ul. Kazimierza Wielkiego — biegła od rynku do Bramy Lwowskiej (Sagan-Bielawa, 2004, s. 225).

${ }^{10}$ Inaczej jest współcześnie; w Przemyślu obecnie mamy dużo nazw konwencjonalnych tworzonych na wzór kierunkowych, np.: Zakopiańska, Legnicka, Dynowska, ale wiele takich onimów wciąż ma motywację realistyczną — kierunkową lub lokalizującą. Utrwalają one nazwy dawnych wsi włączonych w obręb miasta lub położonych tuż obok niego, np.: Sielecka (greckokatolicka wieś Sielec), Bakończycka (wieś Bakończyce zarządzana w XIV wieku przez węgierskiego starostę), Betwińska (wieś Bełwin, wcześniej Lubomierz).

${ }^{11}$ Nestor — kronikarz dawnej Rusi, żyjący na przełomie XI i XII wieku, autor jednego z najstarszych latopisów (kronik ruskich), czyli „Powieści lat minionych”. Dokument ten zawiera najstarsze poświadczenie nazwy Przemyśll. 
Pojedyncze przemyskie urbanonimy utrwalają historię ziem pogranicznych, np. dawną przynależność Przemyśla do Grodów Czerwieńskich zapisano w plateonimie ul. Czerwieńska, a położenie na kresach dokumentuje nazwa Rondo Kresowian. Ciemne karty historii tych ziem przypomina onim Rondo Ofiar Wolynia. Kilka nazw obiektów miejskich utrwala pamięć o Orlętach Przemyskich ${ }^{16}$ - młodych polskich obrońcach miasta przed Ukraińcami i Rosjanami w latach 1918-1921. W mieście znajduje się nie tylko Plac Orląt Przemyskich, ale stanął też Pomnik Orląt Przemyskich oraz Most im. Orląt Przemyskich.

\section{WIELONARODOWOŚĆ — POGRANICZE ETNICZNE}

Przemyśl, jak wiele polskich, a zwłaszcza przygranicznych miast, był miejscem, gdzie mieszały się różne żywioły osadnicze. W średniowieczu oprócz Polaków i Rusinów mieszkali tu sprowadzeni przez Kazimierza Wielkiego osadnicy niemieccy, a także Żydzi oraz — w znacznie mniejszej liczbie — Tatarzy i Ormianie (Wolski, 1957, s. 12). W okresie rozkwitu miasta przybyli tu także włoscy architekci i różnej narodowości (głównie Austriacy i Węgrzy) żołnierze tworzonej twierdzy Przemyśl ${ }^{17}$. Wielonarodowość Przemyśla i związane z nią interferencje kulturowe dokumentują nazwy pamiątkowe, ale też uznaniowe ${ }^{18}$, nadane nie tyle na pamiątkę, ile na cześć określonych osób, wydarzeń, miejsc.

Jak już wspomniano, narodowość na pograniczu polsko-ukraińskim była dość ściśle związana z religią, dlatego spisy mieszkańców, prowadzone od XV wieku

${ }^{12}$ Bohdan Zaleski — romantyczny poeta polski, zaliczany do tzw. szkoły ukraińskiej.

${ }_{13}$ Edward Heil — urodzony w Stryju w 1903 roku uczestnik walk w obronie Przemyśla i Lwowa w 1918 roku, komendant Krakowskiej Chorągwi Szarych Szeregów, żołnierz, rozstrzelany przez Niemców w 1944 roku.

${ }^{14}$ Emilia Gierczak — urodzona w 1925 roku w Maszewie, w woj. wołyńskim, żołnierka, podporucznik, deportowana z Wołynia w 1939 roku, wywieziona do kołchozu, wcielona do armii, brała udział w walkach II wojny światowej.

${ }^{15}$ Podpułkownik Kazimierz Gurbiel — syn oficera armii carskiej, urodzony w Moskwie, od młodości związany z Przemyślem, patriota i bohater, walczył m.in. pod Monte Cassino; pochowany w Przemyślu.

${ }^{16}$ Nazwa powstała przez analogię do Orląt Lwowskich — młodych Polaków walczących o miasto z wojskami ukraińskimi w 1918 roku, w czasie, kiedy nie było tam regularnych oddziałów Wojska Polskiego. Młodzież ta walczyła także z Armią Czerwoną w 1920 roku, w czasie wojny polsko-bolszewickiej. Polegli zostali pochowani na specjalnie wydzielonej części Cmentarza Łyczakowskiego.

${ }^{17}$ W latach pięćdziesiątych XIX wieku, w czasie pogorszenia stosunków między Rosją i Austro-Węgrami, rozpoczęto w Przemyślu budowę ogromnych fortyfikacji. W przededniu I wojny była tu trzecia co do wielkości twierdza w Europie. Stacjonowało w niej około 130 tys. żołnierzy (Wolski, 1957, s. 32-34).

${ }^{18}$ Różnicuję tu terminologicznie nazwy pamiątkowe, upamiętniające osoby, wydarzenia związane $\mathrm{z}$ nazywanym elementem przestrzeni miasta, i nazwy uznaniowe, powstałe $\mathrm{z}$ chęci uczczenia kogoś (czegoś). 
według wyznania, w dużym stopniu odzwierciedlały stan etniczny. Spisy te dowodzą, że odsetek Żydów w mieście rósł aż do końca XVIII wieku. Od połowy XIX wieku do dwudziestolecia międzywojennego oscylował wokół trzeciej części. Blisko jedną piątą mieszkańców stanowili grekokatolicy, a powyżej 40\% rzymskokatolicy. Odsetek osób innej wiary był marginalny (zob. tabelę $\mathrm{nr} 1$ ).

Tabela 1. Liczba mieszkańców Przemyśla z uwzględnieniem wyznania

\begin{tabular}{|c|c|c|c|c|c|}
\hline Rok & $\begin{array}{c}\text { Liczba } \\
\text { mieszkań- } \\
\text { ców miasta } \\
\text { ogólem }\end{array}$ & $\begin{array}{l}\text { Rzymscy } \\
\text { katolicy }\end{array}$ & Grekokatolicy & $\begin{array}{l}\text { Starozakonni } \\
\text { (̇̇ydzi) }\end{array}$ & Inni \\
\hline 1521 & 1100 & \multicolumn{2}{|c|}{$1050(95 \%)$} & $50(5 \%)$ & bd \\
\hline $\begin{array}{l}\text { XVI/ } \\
\text { XVII w. }\end{array}$ & 1579 & \multicolumn{2}{|c|}{$1272(80 \%)$} & $307(20 \%)$ & bd \\
\hline 1668 & 1549 & \multicolumn{2}{|c|}{$1049(68 \%)$} & $500(32 \%)$ & bd \\
\hline 1717 & 1651 & \multicolumn{2}{|c|}{787 (48\%) } & $864(52 \%)$ & bd \\
\hline $\begin{array}{l}\text { koniec } \\
\text { XVIII w. }\end{array}$ & 2902 & \multicolumn{2}{|c|}{$1416(49 \%)$} & $1486(51 \%)$ & bd \\
\hline 1857 & 10140 & $3860(38 \%)$ & $2075(20,5 \%)$ & $4180(41 \%)$ & $25(0,5 \%)$ \\
\hline 1870 & 15185 & $6297(41,5 \%)$ & $2858(19 \%)$ & $5692(39 \%)$ & $68(0,5 \%)$ \\
\hline 1880 & 22040 & $9563(43,5 \%)$ & $4712(21,5 \%)$ & $7645(34,5 \%)$ & $120(0,5 \%)$ \\
\hline 1890 & 35214 & $16671(47,5 \%)$ & $7177(20,5 \%)$ & $10998(31 \%)$ & $368(1 \%)$ \\
\hline 1900 & 46304 & $21320(46 \%)$ & $10429(22,5 \%)$ & $14109(30,5 \%)$ & $446(1 \%)$ \\
\hline 1910 & 54078 & $25306(47 \%)$ & $12018(22 \%)$ & $16062(29,7 \%)$ & $692(1,3 \%)$ \\
\hline 1921 & 47958 & $21942(46 \%)$ & $7459(15,5 \%)$ & $18360(38 \%)$ & $197(0,5 \%)$ \\
\hline
\end{tabular}

Opracowanie własne na podstawie publikacji: „Ludność Przemyśla w latach 1521-1921”

(Kramarz, 1930, s. 11-32, 55, 59, 67, 72, 75, 81, 97).

Najliczniejszą mniejszością w mieście byli Żydzi. Nie wiadomo, kiedy dokładnie przybyli do Przemyśla, ale z całą pewnością można stwierdzić ich obecność za panowania Kazimierza Wielkiego. Źródła dokumentują, że za Zygmunta Augusta mieszkało tu 18 rodzin żydowskich. Przez cały wiek XVII Żydzi rośli w siłę i zamożność, a kroniki z 1740 roku mówią, że przejęli cały handel w mieście (Różański, 2001, s. 7-8). W okresie międzywojennym stanowili blisko 40\% mieszkańców miasta. Niestety, wskutek działań agresorów w czasie II wojny światowej cała społeczność żydowska albo została wymordowana, albo wywieziona, albo uciekła (Wolski, 1957, s. 134). 
Co zostało po wyznawcach judaizmu w onimii miasta? Przede wszystkim wciąż utrzymuje się nieoficjalna nazwa Dzielnica Żydowska, określająca część miasta między ulicami Kazimierza Wielkiego, Jagiellońską i Wodną. Znikła z kolei prastara nazwa, poświadczona już w XV wieku -ul. Żydowska ${ }^{19}$. Nie ma też notowanych w XVII wieku nazw Lwowska - Żydowska i Lwowska - Katolicka, motywowanych narodowością i wyznaniem osób tam zamieszkujących (SaganBielawa, 2004, s. 228). Pamiątką po eksterminacji społeczności żydowskiej jest ul. Bohaterów Getta; poza tym w mieście mamy ul. Juliana Klaczki - nazwa upamiętnia syna kupca żydowskiego, krytyka literackiego, historyka sztuki, publicystę ${ }^{20}$, oraz Rondo Hermana Liebermana, upamiętniające adwokata i publicystę pochodzącego z Drohobycza, którego symboliczny grób znajduje się na przemyskim kirkucie ${ }^{21}$. W mieście niegdyś były dwa miejsca pochówku Żydów. Do dziś pozostało jedno: Cmentarz Żydowski, położony w sąsiedztwie Cmentarza Komunalnego; jest to największa żydowska nekropolia na Podkarpaciu, założona w 1822 roku. Po drugim, zwanym Starym Cmentarzem Żydowskim, wymienianym już w 1568 roku, zachowała się do dziś tylko brama — został doszczętnie zniszczony w czasie II wojny światowej.

Drugą pod względem liczebności mniejszość stanowili prawosławni Ukraińcy. Po wojnie większość z nich została wywieziona — najpierw na wschód, a potem na tzw. Ziemie Odzyskane. Ci, którzy zostali, częściowo się zasymilowali. Ukraińskie wpływy językowe i religijne zostaną omówione dalej. W tym miejscu warto wspomnieć dwie nazwy: pamiątkowy plateonim ul. Tarasa Szewczenki, upamiętniający ukraińskiego poetę narodowego i działacza politycznego, skazanego za pisanie w języku ukraińskim i promowanie niepodległości Ukrainy, oraz urbochrematonim Narodnyj Dim — sygnujący dom ludowy zbudowany na początku XX wieku ze składek przemyskich Ukraińców, po wojnie przejęty przez skarb państwa, zwrócony pierwotnym właścicielom dopiero po wielu zabiegach w 2011 roku. Nazwy te są jednak odosobnione, bowiem ze względu na „złą pamięć” i negatywne emocje towarzyszące powojennym stosunkom polsko-ukraińskim, w urbanonimii Przemyśla nie utrwalono nazw odwołujących się do tej narodowości.

${ }^{19}$ M. Sagan-Bielawa (2004, s. 228) dowodzi, że nazwa związana jest z osadą o nazwie $\dot{Z} y d z i$, znajdującą się poza murami Przemyśla; pierwotnie była to zatem nazwa kierunkowa, już jednak w XVIII wieku ulica ta stała się rzeczywiście centrum powstającej wówczas Dzielnicy Żydowskiej. Osadę o nazwie Żydzi wspomina np. spis podymnego z 1668 roku, w którym wymieniane są trakty: Z rynku do żydów, Od Franciszkanów do żydów, Między żydami (Kramarz, 1930, s. 28).

${ }^{20}$ Julian Klaczko, właśc. Jehuda Lejb (1825-1906), syn kupca Hersza Lejba i Taby Lei Gruendberg, ochrzczony w 1856 roku; po upadku powstania styczniowego działał w Galicji na rzecz zbliżenia z rządem austriackim.

${ }^{21}$ Herman Lieberman (1870-1941), urodzony w rodzinie zasymilowanych Żydów, w dzieciństwie posługiwał się imieniem Hersz. Jako prawnik pracował w Rzeszowie i Przemyślu; żołnierz I wojny światowej. 
Przemyśl za Kazimierza Wielkiego był zasiedlany Niemcami, ale w nazewnictwie miejskim z tego czasu nic nie zostało. Trochę więcej wpływów niemieckich na urbanonimię wystąpiło w wiekach XVI i XVII, kiedy to arystokrację miejską stanowili przybysze z zachodu (nie tylko z Niemiec, ale też z Włoch). Bogatych mieszczan upamiętniają urbochrematonimy: Kawiarnia Stiebera — najelegantsza w Przemyślu, mieszcząca się w hotelu Royal; kamienica Pod Krzysztofory położona w płd. pierzei rynku, własność Krzysztofa Helznera (na jej fasadzie znajdowała się figura św. Krzysztofa); Kamienica Bononiowska — znajdująca się w płn. pierzei rynku, będąca własnością słynnego włoskiego architekta Andrzeja Bononiego; Kamienica Adrianowska - ulokowana w rynku, należąca do bogatych kupców pruskich, nazwana od imienia jednego z nich Adriana Helznera, Kamienica Korniaktów, Kamienica Hildów i inne (Różański, 2001, s. 5-15; Wolski, 1957, s. 63-66). Jeszcze w dwudziestoleciu międzywojennym przewodniki po Przemyślu dokumentują nazwy eleganckich restauracji, sygnowanych obcymi nazwiskami właścicieli: Jakób Huber, Hartmayer w hotelu Victorya, Oschenberg, Jan Szlagor (Orłowicz, 1917, s. 9).

Ślady politycznej zależności Przemyśla i regionu od Austro-Węgier odnajdujemy w nazwie drogi łączącej Przemyśl przez Duklę z Węgrami — onim Trakt Węgierski był w użyciu jeszcze w dwudziestoleciu międzywojennym (Orłowicz, 1917, s. 102). Z napływem cudzoziemców z Austro-Węgier (ale też z innych krajów) do miasta mamy do czynienia od 1873 roku — był to początek rozbudowy Twierdzy Przemyśl. Przybysze pozostawili ślady nie tylko w architekturze, ale także w onimii: wśród zachowanych do dziś nazw fortów znajdują się miana pamiątkowe, np. Fort Salis Soglio, nazwany na cześć Daniela Salis-Soglio, dyrektora budowy umocnień, Fort Bruner, utrwalający nazwisko projektanta Moritza von Brunnera, Fort Werner, dokumentujący nazwisko projektanta inż. Antona Wernera. Z języka francuskiego pochodzi ciekawa nazwa Fort San Rideau, utworzona od wyrazu rideau 'zasłona, kotara' - fort miał stanowić osłonę linii rzeki San od wschodu.

Kolejną warstwę onimów dokumentujących wielonarodowość stanowią nazwy miejsc pamięci - echa walk i wojen, najpierw z Tatarami (Kopiec Tatarski i ul. Tatarska), a potem z Ukraińcami, Rosjanami i Niemcami. Nazwy licznych cmentarzy wojskowych z XX wieku są motywowane narodowością poległych (Ukrainski Cmentarz Wojenny ${ }^{22}$, Niemiecki Cmentarz Wojenny ${ }^{23}$, a także cztery cmentarze zgrupowane w Zespole Cmentarzy Wojennych Twierdzy Przemyśl: Cmentarz Żotnierzy Rosyjskich, Cmentarz i Mauzoleum Żotnierzy Niemieckich

22 Założony około 1920 roku dla jeńców Armii Zachodnio-Ukraińskiej Republiki Ludowej $\mathrm{i}$ internowanych żołnierzy walczących pod dowództwem Semena Petlury.

${ }^{23}$ Oddany do użytku w 1995 roku; złożono tu szczątki około 4000 żołnierzy niemieckich poległych w czasie II wojny światowej. 
oraz dwa Cmentarze Żotnierzy Austro-Wegierskich). Rzadziej nazwy pochodzą od lokalizacji nekropolii (cmentarz Zasanie ${ }^{24}$ ).

Najnowszą warstwę urbanonimów stanowią te, które dokumentują współczesne kontakty z innymi narodami. Miastem partnerskim Przemyśla jest Paderborn w Niemczech; utrwalono je w onimie Rondo Paderborn; z kolei ul. Heidi Wernerus-Neumann upamiętnia nazwisko niemieckiej aktywistki społecznej i samorządowej, jednej z inicjatorek nawiązania współpracy pomiędzy miastami Paderborn i Przemyśl, założycielki Towarzystwa Przyjaciół Przemyśl — Paderborn, działaczki na rzecz zbliżenia Niemców i Polaków, Honorowego Obywatela Miasta Przemyśla. W mieście są też: ul. Węgierska, ul. Grenada oraz Skwer Wyszehradzki.

\section{POGRANICZE JEZZYKOWE}

Zróżnicowana etnicznie i wyznaniowo ludność Przemyśla posługiwała się głównie trzema językami: polskim, ukraińskim i jidysz. Marginalny odsetek mieszkańców mówił po niemiecku lub włosku. Poniższa tabela wskazuje relacje językowe panujące na przełomie XIX i XX wieku, ustalone na podstawie dokumentów spisów podatkowych. Dane te jednak do pewnego stopnia zaciemniają, a nawet fałszują obraz stosunków językowych w tej okolicy.

Tabela 2. Liczba i odsetek mieszkańców Przemyśla w zależności od języka

\begin{tabular}{|c|c|c|c|c|c|}
\hline \multirow{2}{*}{ Rok } & \multicolumn{5}{|c|}{ Język } \\
\cline { 2 - 6 } & polski & ruski & niemiecki & jidysz & inne \\
\hline \multirow{2}{*}{1880} & 18838 & 1659 & 1117 & 0 & 76 \\
& $86 \%$ & $7,6 \%$ & $5,4 \%$ & & $0,3 \%$ \\
\hline 1900 & 32438 & 3946 & 1193 & 0 & 159 \\
& $86,1 \%$ & $10,4 \%$ & $3,1 \%$ & & $0,4 \%$ \\
\hline \multirow{2}{*}{1921} & 29523 & 5119 & 69 & 13156 & 89 \\
& $61 \%$ & $10,7 \%$ & $0,1 \%$ & $27,5 \%$ & $0,1 \%$ \\
\hline
\end{tabular}

Opracowanie własne na podstawie publikacji „Ludność Przemyśla w latach 1521-1921” (Kramarz, 1930, s. 110).

W wieloetnicznych społecznościach możliwe są sytuacje, że używa się tylko jednego języka, że języki poszczególnych etnosów mają równą pozycję lub występuje mieszanina języków. Czwartą opcją jest istnienie społeczeństwa

${ }^{24}$ Spoczywają tam żołnierze armii austro-węgierskiej, żołnierze polscy z okresu obu wojen światowych, a także zamordowani w latach 1943-1944 żołnierze AK i żołnierze walczący w 1946 roku z UPA. 
dwujęzycznego, przy czym użycie każdego z języków zależne jest od sytuacji komunikacyjnej. Taka sytuacja występowała w Przemyślu i okolicach. Badania prowadzone przez socjologów pokazały, że jeszcze w okresie międzywojennym panował tu swoisty pluralizm językowy: językami narodowymi posługiwano się w domu i w kościele, a w urzędzie, szkole, za bramą domu mówiono po polsku. Po II wojnie światowej, kiedy dokonano czystek etnicznych i zaprzestano nauczania języków mniejszości w szkołach ${ }^{25}$, obserwuje się zjawisko asymilacji językowej. Żydzi przyjeżdżają tu tylko na święta, a młodzi Ukraińcy właściwie mówią wyłącznie po polsku (por. badania D. Wojakowskiego, 2002, s. 144-154).

Język jidysz, jako zupełnie obcy dla Słowian, nie znalazł odbicia w przemyskiej urbanonimii. Inaczej powinno być z językiem ukraińskim. W toponimii pogranicza częste są interferencje językowe dotyczące płaszczyzny fonetycznej, leksykalnej czy morfologicznej tych dwóch języków słowiańskich (zob. np. Koper, 2019; Makarski, 1999 ). W nazewnictwie miejskim jest jednak zupełnie inaczej. Wpływy języków wschodniosłowiańskich możemy obserwować głównie w tych nazwach, które dawniej były toponimami, a — na skutek rozrastania się miasta - stały się urbanonimami: nazwami części miasta, osiedli, a także w nazwach ulic kierunkowych. Nazwą wsi (notowaną już w 1418 roku) motywowane są dwa przemyskie osiedla Kruhel Wielki i Kruhel Mały (ukr. kruh 'krąg, koło'). Współcześnie biegnie tamtędy $u l$. Kruhelska. W mieście są też inne nazwy ulic zachowujące ukraińskie cechy fonetyczne: ul. Nehrebecka (zapisywana już od XVI wieku - Kramarz, 1930, s. 14), biegnąca do wsi, która niegdyś nazywała się Nehrebka, dziś Nehrybka, oraz ul. Dubiecka, prowadząca w kierunku miejscowości Dubiecko (por. pol. $d a ̨ b$, ukr. $d u b$ ). Jedna z części miasta zwana była (nazwa powoli zanika) Błahowiszczenie - onim motywowany jest patrocinium istniejącej tu kiedyś Cerkwi Błahowiszczenia, czyli 'Zwiastowania'. Nieznaczne wpływy ukraińskie można dostrzec w urbochrematonimii. Oprócz wspomnianego wyżej budynku o nazwie Narodnyj Dim (zwanego też po polsku Domem Ukraińskim ${ }^{26}$, mamy w mieście hotel i restaurację o nazwie Trojka, zlokalizowane przy ul. Lwowskiej w Przemyślu.

\section{WIELOWYZNANIOWOŚĆ — POGRANICZE RELIGIJNE}

Przemyśl od wieków był siedzibą dwóch metropolii kościelnych: obrządku łacińskiego oraz wschodniego. Także później znany był z różnorodności religijnej, a w wieku XVII wieku był świadkiem zajadłych walk religijnych (reformacja,

${ }^{25}$ Do lat sześćdziesiątych XX wieku nawet karano za mówienie po ukraińsku. Język ukraiński wrócił do szkół na pograniczu w 1996 roku (Wojakowski, 2002, s. 145).

${ }^{26}$ Warto zaznaczyć, że nazwa egzogeniczna nie jest tłumaczeniem nazwy endogenicznej (por. Popowska-Taborska, 1999, s. 58). 
kontrreformacja, kalwini, arianie, unici, dyzunici) ${ }^{27}$ (Wolski, 1957, s. 22-23). Liczne klasztory i kościoły były największymi budynkami w przestrzeni miejskiej, dlatego stawały się doskonałymi lokalizatorami. Już najstarsze, opisowe nazwania ulic odwołują się do tych elementów krajobrazu, np. piętnasto- i szesnastowieczne zapisy: platea eundo ad ecclesiam - 1439, platea versus Ecclesiam, platea ad ecclesia cathedraly - 1540 (Sagan-Bielawa, 2004, s. 226). W spisie domów z 1629 roku wymieniane są m.in. ulice: Z rynku ku kościołowi, Ku Karmelitom, Władycze, od kościoła katolickiego do Grodzkiej, Z rynku ku farze, Od Franciszkanów ku żydom. W tym samym wykazie wyliczono 193 domy miejskie, 40 szlacheckich i aż 32 domy duchownych (Kramarz, 1930, s. 13).

Lokalizujące nazwy ulic o motywacji realistycznej do dziś licznie występują w toponimii Przemyśla i nadal często odwołują się do budowli sakralnych (ulice: Kapitulna, Katedralna, Klasztorna, Mariacka, Plac Katedralny). Co ciekawe, w mieście nie ma dziś ulic *Cerkiewnej czy *Bożniczej (mimo że zachowały się budynki synagog), ale lokalizatorami są obiekty obu wyznań chrześcijańskich (np. ul. Mariacka biegnie w sąsiedztwie cerkwi Narodzenia Przenajświętszej Bogurodzicy). Temu typowi semantycznemu bliski jest inny model — nazwy tworzone od określeń zgromadzeń zakonnych i godności kościelnych. Strukturalnie przypominają one nazwy posesywne, nie wskazują jednak na „posiadacza”, ale na sąsiedztwo z budynkami będącymi czyjąś własnością, czyli de facto na położenie. Już na dziewiętnastowiecznych mapach katastralnych odnajdziemy nazwy: ul. Franciszkańska, ul. Jezuicka, ul. Reformacka, ul. Biskupia. Nazwy te miały motywację realistyczną, w związku z czym zmieniały się, jeśli ich motywacja przestawała być żywa. Świadczy o tym np. nazwa ul. Pojezuicka na nowszej mapie katastralnej, sporządzonej po kasacji zakonu jezuitów w Przemyślu (Sagan-Bielawa, 2004, s. 226). Do dziś w mieście zachowały się ulice: Biskupia, Felicjanek, Franciszkańska, Karmelicka, Mnisza, Salezjańska, Władycze ${ }^{28}$.

$\mathrm{Z}$ urbochrematonimów motywowanych stosunkami religijnymi wymienić można: Domek Kanoniczny/Domek Orzechowskiego, Folwark oo. Misjonarzy, Gmach Kapitularny, Kamienice Śnigurskiego, Kolegium Jezuickie, później Kolegium Pojezuickie, Szkołę Kapitularną czy Szkołę Katedralna (Wolski, 1957, s. 44-48; Różański, 2001, s. 13-27; Kramarz, 1930, s. 38). Człony określające

27 Wielu badaczy i czytelników (zob. np. Wolski, 1957, s. 43) w mieście opisanym w „Monachomachii” Ignacego Krasickiego widzi właśnie Przemyśl (por. Pieśń I: „W mieście, którego nazwiska nie powiem [...] /. Było trzy karczmy, bram cztery ułomki, / Klasztorów dziewięć i gdzieniegdzie domki"). Tezę tę uprawdopodobnia fakt, że poeta i satyryk urodził się w Dubiecku, uczył we Lwowie, święcenia kapłańskie przyjął w Przemyślu, kilka lat później został kanonikiem tutejszej katedry i objął tu probostwo - mógł więc opisać miasto, w którym żył i pracował.

${ }_{28}$ Jest to bardzo stara, co najmniej siedemnastowieczna nazwa, pochodząca od określenia dawnej jurydyki grekokatolickich biskupów przemyskich; biskupów tego obrządku zwano władykami (Różański, 2001, s. 7; Sagan-Bielawa, 2004, s. 226). 
wszystkich tych nazw są posesywne - motywowane albo nazwiskami właścicieli, albo apelatywnymi określeniami pochodzącymi od tytułów, godności, rodzajów instytucji kościelnych, nazw zgromadzeń.

Także liczne w Przemyślu klasztory i świątynie obu wyznań katolickich najczęściej nazywane były od nazw zgromadzeń (np. Klasztor Benedyktynek, Klasztor Bonifratrów, Klasztor Bazylianów, Kościół Dominikanów, Kościół Reformatów). Czasami — podobnie jak w przypadku nazw ulic — nazwy świątyń utrwalały byłych właścicieli (np. Cerkiew Pobazyliańska, Kościół Pojezuicki). W przypadku kościołów katedralnych członem określającym była nazwa wyznania (katedra greckokatolicka, katedra łacińska, katedra rzymskokatolicka). We współczesnych oficjalnych nazwach utrwalane są: narodowość, wyznanie, ranga świątyni (Cerkiew Bizantyjsko-Ukraińskiej Cerkwi Prawosławnej Narodzenia Przenajświętszej Bogurodzicy, Bazylika Archikatedralna Wniebowzięcia Najświętszej Maryi Panny i św. Jana Chrzciciela/Archikatedra Rzymskokatolicka pw. Wniebowzięcia NMP i św. Jana Chrzciciela; Sobór Archikatedralny św. Jana Chrzciciela/Archikatedra Bizantyjsko-Ukraińska św. Jana Chrzciciela) ${ }^{29}$. Wszystkie kościoły rzymskoi greckokatolickie mają też swoich świętych patronów ${ }^{30}$.

Inaczej zbudowane są nazwy żydowskich domów modlitwy. W Przemyślu było ich pięć: Najstarsza Synagoga ${ }^{31}$, Stara Synagoga ${ }^{32}$, Synagoga Tempel ${ }^{33}$, Synagoga Zasańska ${ }^{34}$ oraz Nowa Synagoga, zwana też Synagoga Scheinbacha ${ }^{35}$. W przeciwieństwie do kościołów rzymsko- i greckokatolickich bożnice nie miały wezwań (patrociniów); określano je, lokalizując w czasie lub przestrzeni. Wyjątkowo w jednej z nazw utrwalono nazwisko inicjatora budowy, działacza żydowskiego Mojżesza Scheinbacha, a w innej — wyraz tempel, oznaczający świątynię, a nawiązujący, po pierwsze, do krakowskiej synagogi, zwanej też Postępową (ze względu na jej „nieortodoksyjność”, m.in. sprawowanie nabożeństw po polsku), po drugie, do zburzonej świątyni Salomona w Jerozolimie.

Od XIX wieku w urbanonimii rozwija się moda na nazwy uznaniowe. Patronami ulic stawali się artyści, politycy, naukowcy, a przed wojną — także

${ }^{29}$ Znamienne, że archikatedrom obu obrządków patronuje ten sam święty.

${ }^{30}$ O patrociniach przemyskich świątyń zob. Myszka (2020, s. 110-111).

${ }^{31}$ Drewniana, zbudowana w 1560 r. przez imigrantów z Hiszpanii, spalona już rok później.

${ }^{32}$ Zbudowana na miejscu starszej, drewnianej, w centrum Dzielnicy Żydowskiej, przy ul. Jagiellońskiej pod koniec XVI wieku, zburzona po II wojnie światowej.

33 Wzniesiona w latach 1886-1890 przy ul. Jagiellońskiej, zburzona po wojnie; była jedyną synagogą, w której modlono się po polsku.

${ }^{34}$ Zbudowana na Zasaniu w latach 1890-1892, w czasie wojny przerobiona przez Niemców na elektrownię, obecnie opuszczona i zaniedbana.

${ }^{35}$ Wzniesiona w latach 1910-1918 przy ul. Słowackiego. W czasie II wojny światowej Niemcy urządzili tu stajnię dla koni, dlatego budynek ocalał; przez wiele dziesięcioleci była tam biblioteka; obecnie został zwrócony Żydom. 
święci i duchowni. Ci ostatni, zdjęci z tabliczek adresowych w epoce PRL-u, w ostatnich dekadach triumfalnie powrócili. W Przemyślu plateonimów utrwalających świętych i duchownych jest wyjątkowo dużo ${ }^{36}$. Okazuje się jednak, że zdecydowanie dominują duchowni związani z Kościołem rzymskim, np. ul. bpa Józefa Sebastiana Pelczara, ul. ks. Jerzego Popietuszki, ul. Piotra Skargi, ul. kard. Stefana Wyszyńskiego, ul. ks. Stanistawa Stojałowskiego, ul. ks. Ignacego Skorupki, ul. ks. Stanisława Brzóski, ul. św. Andrzeja Boboli, ul. św. Brata Alberta, także lokalni księża: ul. bpa Jakuba Glazera, ul. bpa Karola Józefa Fischera, ul. ks. Jakuba Federkiewicza, ul. ks. Jana Balickiego, ul. ks. Józefa Ziemiańskiego, Most im. ks. Franciszka Winnickiego, Wiadukt im. ks. pptk. Władysława Deca, rondo Arcybiskupa Ignacego Tokarczuka, Wiadukt im. bt. ks. Bronistawa Markiewicza. W tej grupie lokalnych duchownych są też biskupi i kapłani obrządku greckiego, np. ul. bpa Antoniego Radytowskiego, ul. bt. bpa Jozafata Kocyłowskiego, ul. bpa Jana Śnigurskiego, ul. ks. Antoniego Dobriańskiego, ul. ks. Jana Mogilnickiego. Wśród patronów znajdziemy ponadto duchownego, który urodził się w rodzinie prawosławnej, potem przeszedł na arianizm, w końcu został karmelitą (i bohaterskim obrońcą Przemyśla przed Tatarami): ul. o. Makarego Demeskiego ${ }^{37}$. Oprócz kanonizowanych i beatyfikowanych duchownych patronami ulic zostają także inni święci, np.: ul. św. Jana Nepomucena, ul. św. Józefa, ul. św. Królowej Jadwigi, Plac św. Brunona Bonifacego. Jest też w mieście siedemnastowieczna ul. Świętojańska, ale jej nazwa ma (prócz kultowej) dodatkową motywację lokalizującą (położenie przy Katedrze pw. św. Jana).

\section{PODSUMOWANIE}

Nazwy miejskie są postrzegane jako mniej ciekawe, do pewnego stopnia „gorsze” od innych toponimów, jeśli chodzi o badanie relacji pomiędzy językiem a historią i kulturą. Dzieje się tak ze względu na chronologię nazw miejskich, a także rodzaj ich związku z desygnatem - wśród nowszych urbanonimów (powstałych od końca XIX wieku) spory odsetek stanowią te bez motywacji realistycznej, niejako „zewnętrzne”. Ich motywacja nie pochodzi od obiektu, tylko od kreatora, który na dodatek może nie być członkiem lokalnej społeczności ${ }^{38}$. Jest to swoisty rodzaj nazw egzogenicznych — obcych genetycznie nie w sensie językowym, ale raczej kulturowym (por. Popowska-Taborska, 1999, s. 58) ${ }^{39}$. Tymczasem okazuje

${ }^{36} \mathrm{Na} 234$ nazwy odantroponimiczne aż 36 (12\%) utrwala nazwiska świętych i duchownych.

37 https:/www.karmel.pl/wierni-chrystusowi/2/

${ }^{38}$ Przyrost tych nazw nadanych odgórnie przez władze, samorządy, działaczy obserwujemy zwłaszcza w latach 1945-1980. Także współcześnie nazwy miejskie często są nadawane „z klucza” i obejmują słownictwo z określonego pola tematycznego.

${ }^{39}$ Zjawisko to należy odróżnić od egzo- i endonimii mającej związek ze „swoim” i „obcym” tworzywem językowym (por. Włoskowicz, 2021, s. 137-157). 
się, że także nazwy miejskie, i to nie tylko te najstarsze, mogą dokumentować ciekawe zjawiska językowe, kulturowe, historyczne itp.

W przypadku nazewnictwa miejskiego interferencje rzadko dotyczą fonetycznych cech językowych (jeszcze rzadziej — morfologicznych); częściej obserwujemy je w warstwie leksyki dotyczącej współistniejących języków, kultur, religii (por. Krasowska, Suchomłynow, 2007, s. 58). Transfer kulturowy można obserwować nie tylko w starszych nazwach z motywacją realistyczną, ale też w nowszych wszak ich twórcy dokonywali wyborów: w nazwach uznaniowych — patronów ulic, którzy reprezentują różne wyznania i kultury, w nazwach pamiątkowych osób i wydarzeń związanych z danym miejscem, w nazwach kierunkowych nazw miejscowości z różnych stron granicy, a w lokalizujących — nazwań miejsc, znaczących budynków, elementów z różnych kultur.

Dla badania interferencji językowych i kulturowych na pograniczach ważne jest, jak dawne i jak długotrwałe są kontakty między poszczególnymi etnosami i religiami, czy wciąż są one żywe, jakich warstw społecznych i jakich sytuacji komunikacyjnych dotyczą/dotyczyły (Wolnicz-Pawłowska, 1998a, s. 398). Dlatego, analizując nazewnictwo na pograniczu polsko-ukraińskim, nie można zapominać o historii politycznej, społecznej i gospodarczej tych ziem: o tym, że były to tereny sporne, że poczucie narodowości zaczęło się tu rodzić stosunkowo późno (wiek XIX), że jedno terytorium dzieliły ze sobą grupy o różnej narodowości i różnym wyznaniu. Na dodatek na ten pluralizm etniczno-religijny do pewnego stopnia nałożyła się struktura stanowa: kultura żydowska identyfikowana była jako mieszczańsko-kupiecka, Rusini to głównie chłopi, a polskość utożsamiana była ze stanem wyższym — szlacheckością i mieszczańskością, co zaważyło „zarówno na późniejszym postrzeganiu kultury ukraińskiej przez Polaków jako „niższej”, jak i na traktowaniu Polaków przez ludność ukraińską jako obszarników-ciemiężycieli” (Wojakowski, 2002, s. 101). Znalazło to wyraz w ponurej dwudziestowiecznej historii tych ziem — procesach nacjonalizacyjnych, które doprowadziły do tego, że społeczność żydowska zniknęła z mapy miasta zupełnie, społeczność ukraińska została rozbita, język ukraiński przestał być językiem nauczania, Kościół greckokatolicki stracił swoją pozycję ${ }^{40}$, a polska polityka językowa opierała się na dążeniu do eliminacji wszelkich egzonimów ${ }^{41}$.

Konsekwencją opisanych powyżej działań i wydarzeń było to, że Ukraińcy i ich język zaczęli być postrzegani jako „gorsi”, a nazwy o obcej proweniencji — jako

${ }^{40}$ Inaczej niż na Lubelszczyźnie (gdzie po unii brzeskiej sytuacja Kościoła wschodniego znacząco się zmieniła - Koper, 2019, s. 342), w zaborze austriackim pozostały cerkwie greckokatolickie; niestety, wiele z nich uległo zniszczeniu lub podupadło, bo wyznawcy zostali wywiezieni na wschód lub na Ziemie Odzyskane.

${ }^{41}$ Władze PRL usiłowały administracyjnie „spolszczyć” wszystkie nazwy ukraińskie; nie doszło do tego po głośnych protestach inteligencji polskiej (zob. Koper, 2019, s. 374-378; Wolnicz-Pawłowska, 1998, s. 456). 
dziwne, ,stare”. O ile w nazewnictwie miejscowym regionu pozostało wiele onimów z naleciałościami ukraińskimi, o tyle w nazewnictwie miejskim przetrwały głównie te, które powstały przez zmianę statusu obiektu (np. dawna wieś stała się osiedlem miejskim). Stosunkowo dużo interferencji dotyczy sfery religii w onimii zachowały się zarówno nazwy świątyń, jak i budynków sakralnych, a w nazwach pamiątkowych utrwalono nazwiska grekokatolików (choć zdecydowanie dominują nazwy utrwalające religię rzymskokatolicką). Być może przyczyna takiego stanu wynika z obserwowanej przez socjologów funkcji sakralnej języka (por. np. rolę języka staro-cerkiewno-słowiańskiego w Kościele greckim, łaciny w rzymskim czy hebrajskiego w judaizmie). Mimo że w Kościele (a konkretnie: w języku liturgii) faktycznie można się dopatrywać czynnika podtrzymującego języki narodowe, to jednak jest on niewystarczający wobec sytuacji społecznej i historycznej. Dla wyznawców określonej religii język jest jej składnikiem w podobnym stopniu, jak np. przyśpiewki ludowe są elementem folkloru. To, jak mówi się za drzwiami kościoła, nie przekłada się na mowę poza nim (por. Wojakowski, 2002, s. 148).

\section{LITERATURA}

Babiński, G. (1997). Pogranicze polsko-ukraińskie. Etniczność - zróżnicowanie religijne — tożsamość [Polish-Ukrainian Borderland. Ethnicity — Religious Diversity — Identity]. Kraków: Nomos.

Babiński, G. (2002). Przemiany pograniczy narodowych i kulturowych — propozycje typologii [Changes in national and cultural borderlands - typology suggestions]. W: R. Stemplowski, A. Żelazko (red.), Polskie pogranicza a polityka zagraniczna u progu XXI wieku [Polish Borderlands and Foreign Policy on the Threshold of the $21^{\text {st }}$ Century] (s. 13-30). Warszawa: PISM.

Budzyński, Z. (1993). Ludność pogranicza polsko-ruskiego $w$ drugiej połowie XVIII w. [The Population of the Polish-Ruthenian Borderland in the Second Half of the $18^{\text {th }}$ Century] (t. I-II). Rzeszów: Wydawnictwo WSP.

Czapla, A. (2011). Nazwy miejscowości dawnej ziemi lwowskiej [Place Names of the Historical Lwów Land]. Lublin: Wydawnictwo KUL.

Czapla, A. (2018). Nazwy miejscowości dawnej ziemi halickiej [Place Names of the Historical Halicz Land]. Lublin: Wydawnictwo KUL.

Czopek-Kopciuch, B. (1988). Nazwy miejscowe dawnej ziemi chetmskiej i betskiej (w granicach dzisiejszego państwa polskiego) [Place Names of the Former Chełm and Bełz Land (Within the Borders of Today's Polish State)]. Wrocław: Zakład Narodowy im. Ossolińskich.

Koper, M. (2017). O nazwach ulic w miejscowościach gminy Lubycza Królewska [About street names in localities of the commune of Lubycza Królewska]. W: M. Koper (red.), Ziemia Lubycka. Geografia, historia, język, kultura [Lubycza Land. Geography, History, Language, Culture] (s. 181-194). Lublin-Lubycza Królewska: Fotokopia.

Koper, M. (2019). Powiat tomaszowski w pejzażu toponimicznym pogranicza polsko-ukraińskiego [The District of Tomaszów in the Toponymic Landscape of the Polish-Ukrainian Borderland]. Lublin: Wydawnictwo KUL. 
Kramarz, W. (1930). Ludność Przemyśla w latach 1521-1921 [The Population of Przemyśl between 1521 and 1921]. Przemyśl: Drukarnia J. Łazora.

Krasowska, H. i Suchomłynow, O. (2007). Interferencja językowa jako jeden z aspektów przejawu pogranicza kultur (na przykładzie Bukowiny) [Linguistic interference as one of the aspects of the manifestation of the borderland of cultures (the case of Bukovina)]. Aktual'ni problemi inozemnoï filologï: Lingvistika ta literaturoznavstvo, 1, 55-59.

Makarski, W. (1986). Nazwy miejscowości dawnej ziemi sanockiej [Place Names of the Former Sanok Land]. Lublin: TN KUL.

Makarski, W. (1999). Nazwy miejscowości dawnej ziemi przemyskiej [Place Names of the Former Przemyśl Land]. Lublin: TN KUL.

Malczewski, J. (2017). Przemyśl na pograniczu polsko-ruskim we wczesnym średniowieczu [Przemyśl on the Polish-Ruthenian Borderland in the Early Middle Ages]. Rzeszów: Pro Carpathia.

Myszka, A. i Wisz, P. (2012). Nazewnictwo ulic Rzeszowa. Historia i współczesność [Names of Streets of Rzeszów. History and the Present Day]. Rzeszów: Fraza.

Myszka, A. (2016). Urbanonimia Rzeszowa. Językowo-kulturowy obraz miasta [The Urbanonymy of Rzeszów. Linguistic and Cultural Image of the City]. Rzeszów: Wydawnictwo UR.

Myszka, A. (2020). Kultura materialna i duchowa utrwalona w podkarpackich urbanonimach wybrane aspekty [Material and spiritual culture recorded in the urbanonyms of Podkarpacie selected aspects]. W: M. Rutkiewicz-Hanczewska i J.B. Walkowiak (red.), Wielkopolska nazwami opisana [Wielkopolska Region Described with Names] (s. 97-120). Poznań: Wydawnictwo PSP.

Niedźwiecka-Iwańczak, N. (2020). Pogranicze [Borderland]. W: E. Opiłowska i in. (red.), Studia nad granicami i pograniczami. Leksykon [Studies on Borders and Borderlands. Lexicon] (s. 283-294). Warszawa: Scholar.

Orłowicz, M. (1917). Ilustrowany przewodnik po Przemyślu i okolicy [Illustrated Guide to Przemyśl and its Surroundings]. Lwów: Zjednoczenie Towarzystw Polskich w Przemyślu.

Popowska-Taborska, H. (1999). Językowe wykładniki opozycji swoi-obcy w procesie tworzenia etnicznej tożsamości [Linguistic exponents of the opposition us/them in the process of creating ethnic identity]. W: J. Bartmiński (red.), Językowy obraz świata [The Linguistic Picture of the World] (s. 57-63). Lublin: Wydawnictwo UMCS.

Sielecki, F. (red.). (1999). Powieść minionych lat [Tale of Bygone Years]. Kraków: Zakład Narodowy im. Ossolińskich.

Rieger, J. (1969), Nazwy wodne dorzecza Sanu [Water Names of the San River Basin]. Wrocław: Zakład Narodowy im. Ossolińskich.

Różański, J. (2001). Przemyśl. Przewodnik historyczno-turystyczny [Przemyśl. Historical and Tourist Guide]. Przemyśl: Drukarnia San Set.

Sagan-Bielawa, M. (2004). Obraz miasta w toponimii dawnego Przemyśla [The picture of the city in the toponymy of the former Przemyśl]. W: H. Kurek i J. Labocha (red.), Studia linguistica Danutae Wesolowska oblata (s. 223-231). Kraków: Universitas.

Sagan-Bielawa, M. (2006). Przestrzeń miejska a nazewnictwo ulic (na przykładzie toponimii Przemyśla) [Urban space and names of streets (based on the toponymy of Przemyśl)]. W: M. Święcicka (red.), Miasto. Przestrzeń zróżnicowana językowo, kulturowo i społecznie [Town. A Linguistically, Culturally and Socially Diverse Space] (s. 405-415). Bydgoszcz: Wydawnictwo UKW.

Walczak, B. (1999). Zarys dziejów języka polskiego [An Outline of the History of the Polish Language]. Wrocław: Wydawnictwo UW.

Włoskowicz, W. (2021). Uzus toponimiczny. Zarys teorii na przykładzie polskiej toponimii Huculszczyzny [Toponymic Usus. An Outline of Theory on the Example of the Polish Toponymy of the Hutsul Region]. Kraków: PAN. 
Wojakowski, D. (2002). Polacy i Ukraińcy. Rzecz o pluralizmie i tożsamości na pograniczu [Poles and Ukrainians. About Pluralism and Identity on the Borderland]. Kraków: Nomos.

Wolnicz-Pawłowska, E. (1998). Pogranicze wschodnie [Eastern borderland]. W: E. Rzetelska-Feleszko (red.), Polskie nazwy własne. Encyklopedia [Polish Proper Names. Encyclopedia] (s. 453-466). Warszawa-Kraków: TNW-IJP PAN.

Wolnicz-Pawłowska, E. (1998a). Wprowadzenie [Introduction]. W: E. Rzetelska-Feleszko (red.), Polskie nazwy własne. Encyklopedia [Polish Proper Names. Encyclopedia] (s. 397-399). Warszawa-Kraków: TWNW, IJP PAN.

Wolski, K. (1957). Przemyśl i okolice [Przemyśl and its Surroundings]. Przemyśl: Oddział PTTK w Przemyślu.

\section{SUMMARY}

LINGUISTIC AND CULTURAL INTERFERENCES IN THE URBANONYMY OF PRZEMYŚL

Przemyśl used to be a fortified border town between the Kingdom of Poland and Kievan Rus. The influence of various languages, religions or nationalities existed in that area for centuries, and the numerous traces of such interference can be observed in the toponymy of the region. The aim of this article is to attempt to answer the question to what degree the complex linguistic and national and religious relations have been reflected in both contemporary and old urban names, which are younger and more changeable than settlement names.

The impact of the location of a fortified town was analyzed, as well as the reflection of national (the ethnic border) and religious (the multiconfessionalism of city dwellers) relationships in urbanonyms and linguistic interference. The conducted analysis has shown that the complicated past of the region has had only a slight impact on the contemporary onomastics, but cannot be ignored. The influence of the language and culture of ethnic and religious minorities on the urbanonyms is mostly noticeable in the names motivated by religion, and less so in localizing, cultural or commemorative names.

Keywords: urbanonyms, linguistic and cultural borderline, interferences, Przemyśl 